Article

\title{
Further Studies on the Pyrolytic Domino Cyclization of Stabilized Phosphonium Ylides Bearing an Ortho-Aminophenyl Group
}

\author{
R. Alan Aitken* (D), Lorna Murray and Alexandra M. Z. Slawin \\ EaStCHEM School of Chemistry, University of St Andrews, North Haugh, St Andrews, Fife KY16 9ST, UK; \\ Lorna.Murray@ed.ac.uk (L.M.); amzs@st-and.ac.uk (A.M.Z.S.) \\ * Correspondence: raa@st-and.ac.uk; Tel.: +44-1334-463865
}

Received: 27 July 2018; Accepted: 24 August 2018; Published: 27 August 2018

\begin{abstract}
Four new, stabilized phosphonium ylides containing a 2-(benzyl(methyl)amino)phenyl group have been prepared and characterized and are found, upon pyrolysis under gas-phase flow conditions, to lose $\mathrm{Ph}_{3} \mathrm{PO}$ and benzyl radicals to afford new heterocyclic products resulting from domino cyclization of both $\mathrm{C}$ - and $\mathrm{N}$-centered radicals. Most products arise from processes of the former type and have quinoline, phenanthridine, or ring-fused phenanthridine structures, while in one case, a process of the latter type leads to a benzocarbazole product. The X-ray structure of a 2-(methyl(tosyl)amino)phenyl ylide is also reported.
\end{abstract}

Keywords: phosphonium ylide; pyrolysis; quinoline; phenanthridine; benzocarbazole; X-ray structure

\section{Introduction}

The synthetic use of flash vacuum pyrolysis (FVP) is now well-established and provides the method of choice to obtain certain, otherwise inaccessible products [1]. Particularly in the area of heterocyclic chemistry, the method has been applied to a wide variety of reaction types and product classes [2]. The inherent advantages of a clean, solvent-, reagent-, and catalyst-free method are further enhanced if several reaction steps can be achieved in sequence in a single gas-phase flow pyrolysis process, which is a good example of the "domino" reaction approach [3-5]. In previous studies we have developed a series of methods for the synthesis of fused-ring heterocyclic compounds by FVP of suitably designed carbonyl-stabilized phosphonium ylides. The principle is demonstrated by the case of ylide $\mathbf{1}$, which, at $850^{\circ} \mathrm{C}$, eliminates both triphenylphosphine oxide and a methyl radical (Scheme 1). The resulting alkynylphenoxyl radical 2 undergoes spontaneous 5-endo-dig cyclization to give the benzofuryl radical 3, bearing a suitably-placed styryl group to undergo (after $E / Z$ isomerization) an intramolecular $S_{H} A r$ process, leading to the fused ring product naphtho[2,1-b] benzofuran 4 in $44 \%$ isolated yield [6,7]. Interestingly, in this case a second isomeric product 5 could also be identified in $14 \%$ yield resulting from a rearrangement of 3 prior to cyclization. 


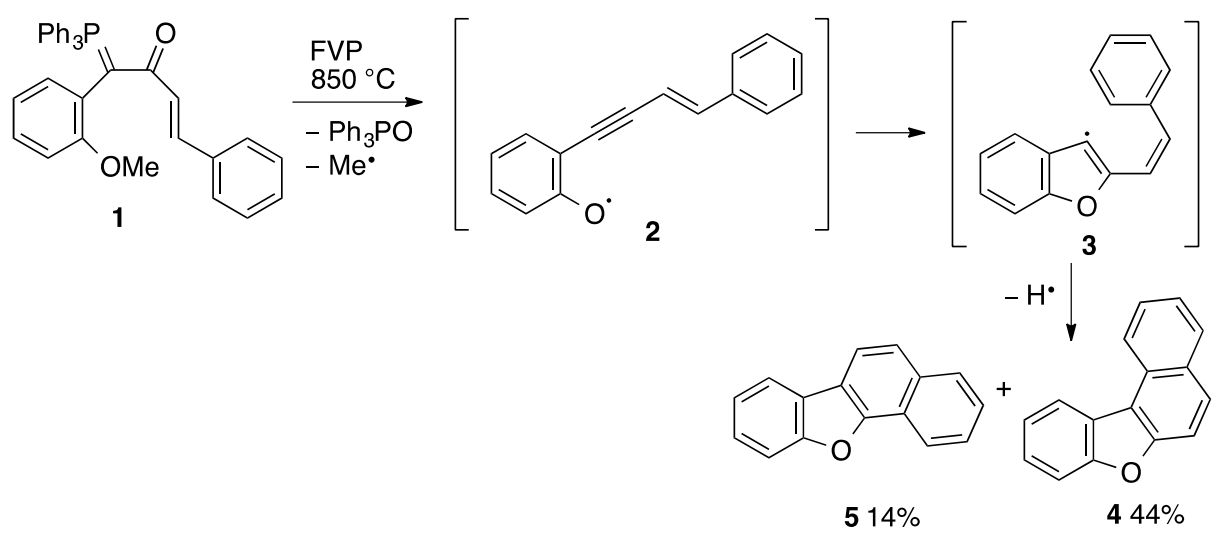

Scheme 1. Example of the domino cyclization approach to fused-ring heterocycles.

The method was later extended to a wide range of examples, including an eight-stage cascade process leading from allyloxy ylide 6 to the 7-(2-benzothienyl)benzofuran 7 (Scheme 2) [8], formation of thieno[2,3-b]pyridine products including the benzofurothienopyridine 9 from ylide 8 [9], formation of a iminobenzopyranone $\mathbf{1 1}$ from ylide $\mathbf{1 0}$ [10], and synthesis of a wide range of products with structure 13, including 24 different fused-ring systems from the general starting ylide structure 12 [11].<smiles>C=CCOc1ccccc1C(=O)C(=P)c1ccccc1SC</smiles>

6<smiles>COc1ccccc1C(=P)C(=O)c1cccnc1S(C)(=O)=O</smiles>

8<smiles>COc1ccccc1C(=Nc1ccccc1)C(=P)C(=O)C=Cc1ccccc1</smiles>
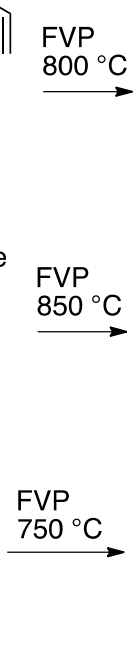<smiles>N=c1cc([Sb](=O)(=O)/C=C/c2ccccc2)oc2ccccc12</smiles><smiles>c1ccc2c(c1)oc1c3ccccc3sc21</smiles>

$931 \%$

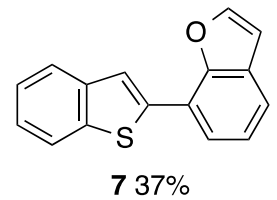

$737 \%$

$1146 \%$<smiles>[X][Y]1cccc1C=C([R])C(=O)C(=P)C(=P)c1cc2ccccc2[nH]1</smiles>
$\mathrm{R}^{3}$

$$
\begin{aligned}
& \mathrm{FVP} \\
& 850^{\circ} \mathrm{C} \\
&-\mathrm{Ph}_{3} \mathrm{PO} \\
&-\mathrm{Me}^{\circ}
\end{aligned}
$$

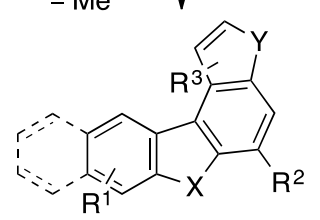

1332 examples

Scheme 2. The range of previously reported cyclizations involving O or S.

All the preceding examples rely on cyclization of phenoxyl or thiophenoxyl radicals, and extension of the method to ylides with a nitrogen-based cyclizing radical introduces an unexpected complication. Preparation of the ylides requires a carbon-based protecting group on nitrogen as well as the leaving group, and transfer of the reactive site from $\mathrm{N}$ to $\mathrm{C}$ may lead to different products. Thus, while simpler ylides, such as the $\mathrm{N}$-methyl- $\mathrm{N}$-tosyl compound 14, give the 3-substituted quinoline $\mathbf{1 5}$ resulting from cyclization of $-\mathrm{NH}-\mathrm{CH}_{2}$ (Scheme 3), the more extended cinnamoyl-type analogues 16-18 do undergo the expected cyclization of $-\mathrm{N}(\mathrm{Me})$ to give ring-fused carbazole products, 19-21 [12]. 

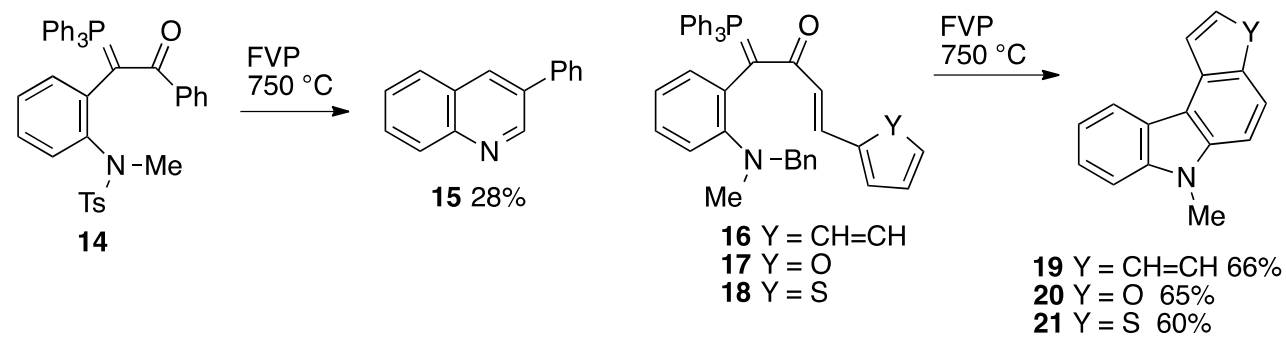

Scheme 3. Divergent outcomes resulting from cyclization involving $\mathrm{C}$ or $\mathrm{N}$.

However, when $\mathrm{N}, \mathrm{N}$-dibenzyl ylides 22-25 were examined, a more complex picture emerged [13] with all four examples giving mainly the styrylquinoline products 27 (Scheme 4 ) as mixtures of $(Z)$ and (mainly) (E)-isomers, together with the ring-fused carbazoles $\mathbf{2 6}$ for ylides $\mathbf{2 2}$ and $\mathbf{2 5}$ only, and the product 28 resulting from further cyclization of 27 from 25 only. The loss of a phenyl group in formation of products $\mathbf{2 7}$ and $\mathbf{2 8}$ is notable, and only for compound $\mathbf{2 4}$ were the products $\mathbf{2 9}$ and $\mathbf{3 0}$ retaining the $N$-benzyl-derived phenyl obtained.

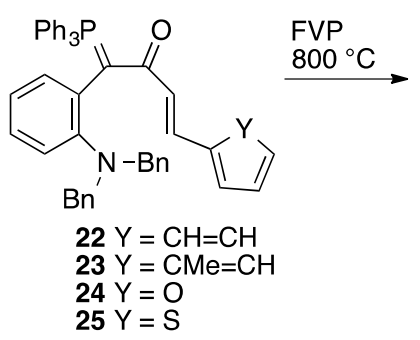<smiles></smiles>

26<smiles>C(=C/c1cc2ccccc2nc1-c1ccccc1)\c1ccco1</smiles>

29<smiles>[Y]1cccc1C=Cc1cnc2ccccc2c1</smiles>

27<smiles>c1ccc(-c2nc3ccccc3c3c2ccc2occc23)cc1</smiles><smiles>c1ccc2c(c1)ccc1sccc12</smiles>

28

30

Scheme 4. Heterocyclic products derived from $N, N$-dibenzyl ylides.

It is clear from these results that it is not yet possible to predict the pyrolysis outcome for the amino-functionalized ylides with any degree of certainty and further work is required to fully understand the processes involved. In this paper, we describe the synthesis and characterization of four new amino-functionalized ylides and the results of their pyrolysis, which leads to the formation of seven new fused-ring heterocyclic products.

\section{Results}

\subsection{X-ray Structure Determination of Ylide $\mathbf{1 4}$}

Since many of the previously studied nitrogen-containing ylides were formed in disappointing yield and showed severe restricted rotation leading to very broad signals in their room temperature NMR spectra [12,13], it was clear that steric hindrance may be an important factor in their reactivity. To examine this further, we have determined the structure of the $N$-methyl- $N$-tosyl ylide 14 [12] by X-ray diffraction. The resulting structure (Figure 1) confirms that this is indeed a sterically congested molecule with the two very bulky ortho substituents on the central benzene ring scarcely able to fit. Within the crystal there are no significant intermolecular interactions. The following bond lengths within the keto ylide functionality: $\mathrm{P}(7)-\mathrm{C}(7)$ 1.746(2), $\mathrm{C}(7)-\mathrm{C}(8)$ 1.408(2), $\mathrm{C}(8)-\mathrm{O}(8)$ 1.263(2) A are indicative of a good degree of delocalization and a high contribution from the charge-separated structure with $\mathrm{P}^{+}-\mathrm{C}=\mathrm{C}-\mathrm{O}^{-}$rather than $\mathrm{P}=\mathrm{C}-\mathrm{C}=\mathrm{O}$. The torsion angle $\mathrm{P}(7)-\mathrm{C}(7)-\mathrm{C}(8)-\mathrm{O}(8)$ is $-9.0(2)$, 
which is within the range normally expected for keto-stabilized ylides [14,15], and indicates a high probability of successful thermal extrusion of $\mathrm{Ph}_{3} \mathrm{PO}$, as does the low value of $6 \mathrm{~Hz}$ [12] for ${ }^{2} \mathrm{~J}_{\mathrm{P}-\mathrm{CO}}$.
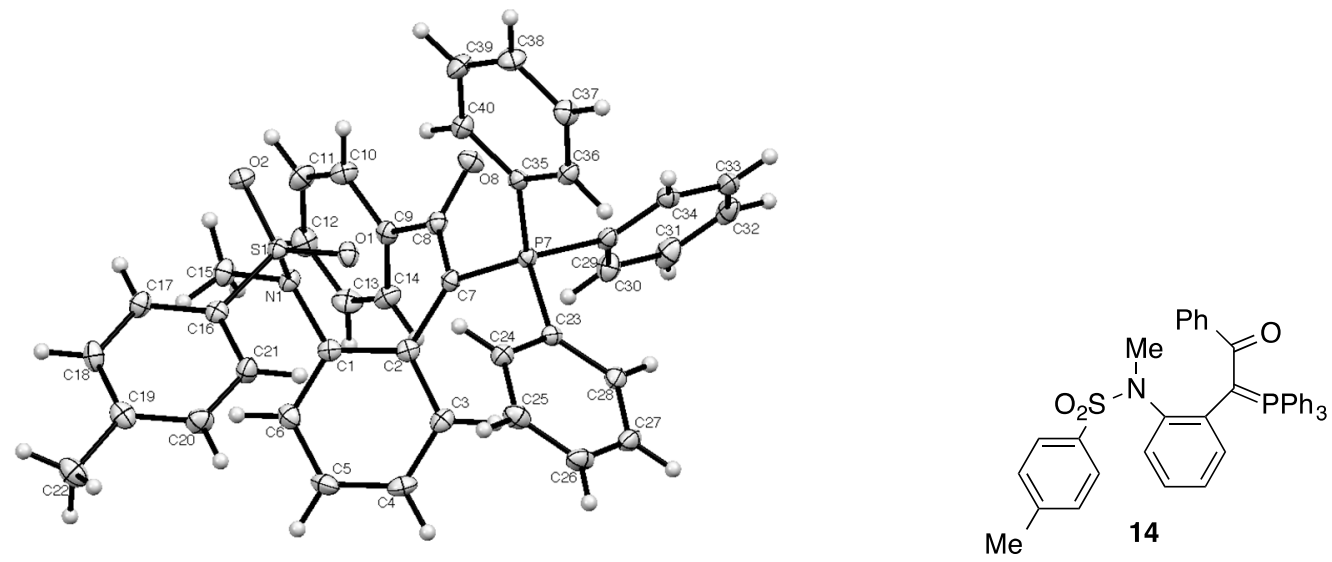

Figure 1. X-ray structure of ylide 14 (ORTEP diagram, 50\% level).

\subsection{Preparation and Characterization of Ylides $\mathbf{3 5 - 3 8}$}

The four new ylides chosen for study have structures 35-38 (Scheme 5). Compounds 35 and 36 are obviously isomeric with ylides 17 and 18, which were well-behaved upon pyrolysis and gave the ring-fused carbazoles [12], but whose dibenzyl analogues 24 and 25 showed more varied and unpredictable behaviour [13]. The 2-methylcinnamoyl ylide 37 is similarly the analogue of dibenzyl ylide 23, and both it and its thiophene analogue $\mathbf{3 8}$ are of additional interest, since we previously observed cyclization involving the methyl group to give vinylnaphthalenes and further cyclized products when ylides analogous to 37 and 38 but only lacking the benzylmethylamino group were subjected to FVP $[16,17]$. As we described previously, it was advantageous to prepare the ylides using $\mathrm{N}$-acylbenzotriazoles as the acylating agents [18] rather than acid chlorides, and the four required benzotriazole derivatives 31-34 (see Supplementary Material S1-S7) were prepared by treatment of the appropriate carboxylic acids with thionyl chloride (1 equiv.) and benzotriazole (4 equiv.).

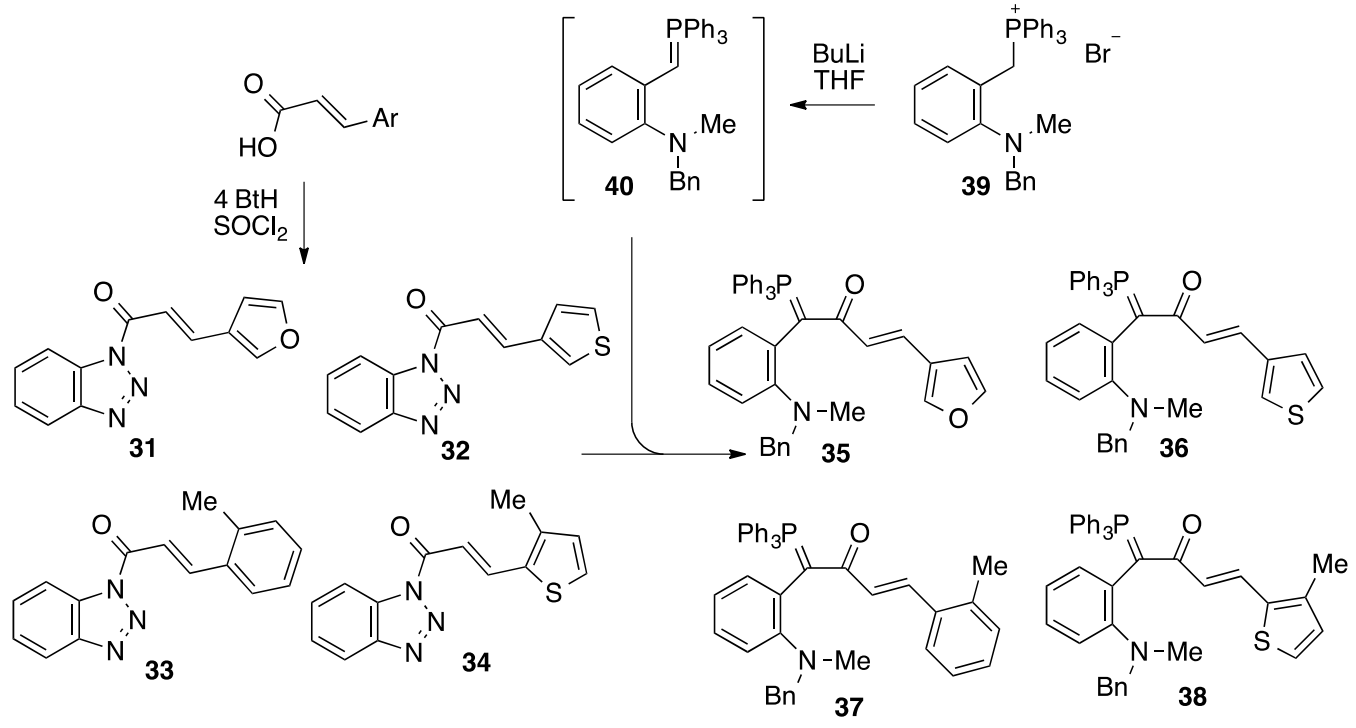

Scheme 5. Preparation of ylides 35-38.

The four ylides were prepared as shown in Scheme 5 by treatment of phosphonium salt 39 [12] with butyllithium to generate the ylide 40 , followed by addition of the appropriate $\mathrm{N}$-acylbenzotriazole, 
and were obtained as stable crystalline solids with high melting points. The signals due to the $P$-phenyl groups in the ${ }^{1} \mathrm{H}$ NMR spectra were very broad, presumably due to similar steric hindrance and restricted rotation to that revealed by the X-ray structure of $\mathbf{1 4}$. The situation was significantly improved by running the spectra at $55^{\circ} \mathrm{C}$, as illustrated in the case of $\mathbf{3 6}$ (see Supplementary Material), and the ${ }^{13} \mathrm{C}$ NMR spectra for all four new ylides were run at this temperature. The value of the two-bond coupling between $\mathrm{C}=\mathrm{O}$ and $\mathrm{P}$ was $5-7 \mathrm{~Hz}$ in each case, indicating a good prospect for successful thermal extrusion of $\mathrm{Ph}_{3} \mathrm{PO}[14]$.

\subsection{Flash Vacuum Pyrolysis to Give Heterocyclic Products}

The first ylide to be pyrolyzed, the 3-furyl compound 35, gave a surprising result. There was complete reaction at a furnace temperature of $700{ }^{\circ} \mathrm{C}$ with formation of $\mathrm{Ph}_{3} \mathrm{PO}$ and bibenzyl-as expected-but the sole heterocyclic product identified in low yield did not contain a furan ring at all and was identified as the 9-methylphenanthridine 41, by comparison of its ${ }^{1} \mathrm{H}$ NMR data with literature values. A suggested mechanism for formation of this product (Scheme 6) involves initial extrusion of $\mathrm{Ph}_{3} \mathrm{PO}$ and benzyl radical followed by transfer of the reactive site from $\mathrm{N}$ to $\mathrm{C}$, by means of a hydrogen atom transfer. Cyclization of the $\mathrm{NH}-\mathrm{CH}_{2}$ onto the triple bond, aromatization, and further cyclization gives an intermediate that could very easily lose a hydrogen atom to form the expected furo[3,2-k]phenanthridine. However, this is apparently not favorable, and instead, ring-opening of the dihydrofuran ring, followed by rearrangement and loss of carbon monoxide leads to the observed stable methylphenanthridine product.

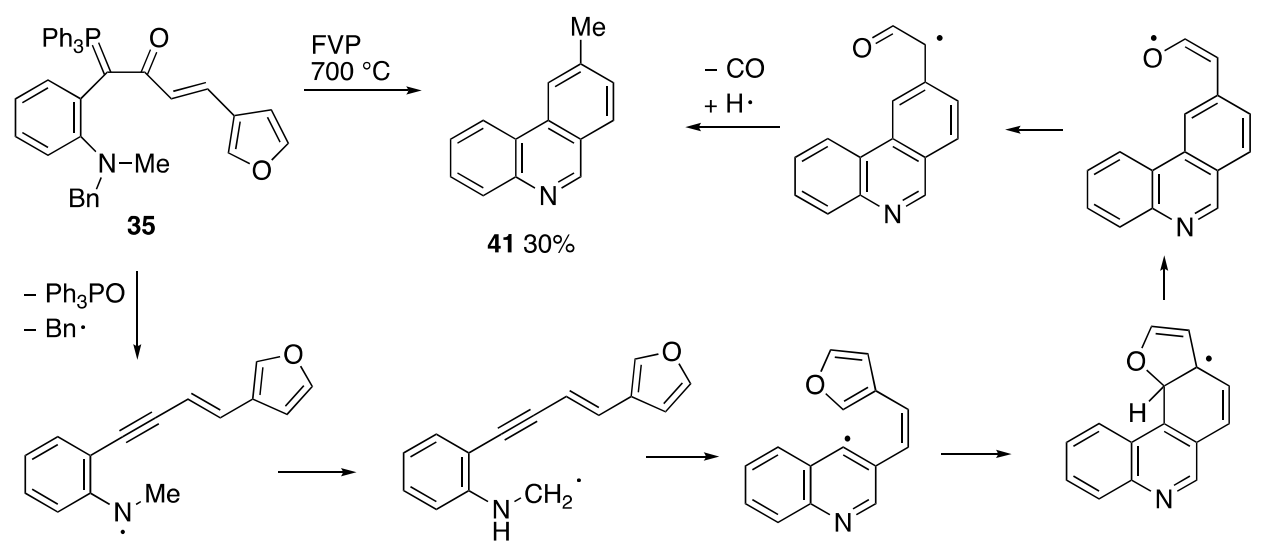

Scheme 6. Flash vacuum pyrolysis (FVP) of ylide 35 to form 41.

By way of contrast, the 3-thienyl ylide 36 behaved analogously to the $N, N$-dibenzyl 2-thienyl ylide 25 [13] with mainly quinoline products 42 , accompanied by a small amount of the tetracyclic thieno[3,2-k]phenanthridine 43 formed by a further cyclization event (Scheme 7). The latter product showed a distinctive ${ }^{1} \mathrm{H}$ NMR spectrum (Supplementary Material S22) which, though complex, was successfully analyzed to derive all coupling constants using simulation. Both chemical shifts and coupling constants were in good agreement with those already reported for the isomeric system 28 [13], thus supporting the structural assignment. Clearly, in this case, the process initially involves extrusion of $\mathrm{Ph}_{3} \mathrm{PO}$ and benzyl radical, hydrogen atom transfer, and cyclization, as shown in Scheme 6-but the greater thermodynamic stability of the thiophene ring means that it survives to appear in the products. The contrast between the behaviour shown here for 35 and 36 and that for the corresponding 2-furyl and 2-thienyl isomers 17 and 18, which give exclusively fused-ring carbazole products 20 and 21 [12], is most surprising. The balance between the $\mathrm{N}$ - and $\mathrm{C}$-centered radical as the cyclizing species is obviously delicate. 
<smiles>CN(C)c1ccccc1C(=P)C(=O)/C=C/c1ccsc1</smiles>

$\mathrm{Bn}$

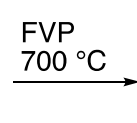

36<smiles></smiles>

(E) $-4228 \%$

(Z) $-42 \quad 15 \%$<smiles></smiles>

$438 \%$

Scheme 7. FVP of ylide 36 to form 42 and 43 .

This fact was emphasized by the result in the case of the 2-methylstyryl ylide 37 (Scheme 8). This is the methyl analogue of $\mathbf{1 6}$ which gave the benzocarbazole product $\mathbf{1 9}$ as the only major product in $66 \%$ yield [12]. Although products derived from cyclization of a $C$-centered radical, the quinolines 44 and the benzophenanthridine 45 , amounted together to $33 \%$, the largest single product was now the dimethylbenzocarbazole 46 , resulting from direct cyclization of an $\mathrm{N}$-centered radical, formed in $22 \%$ yield.
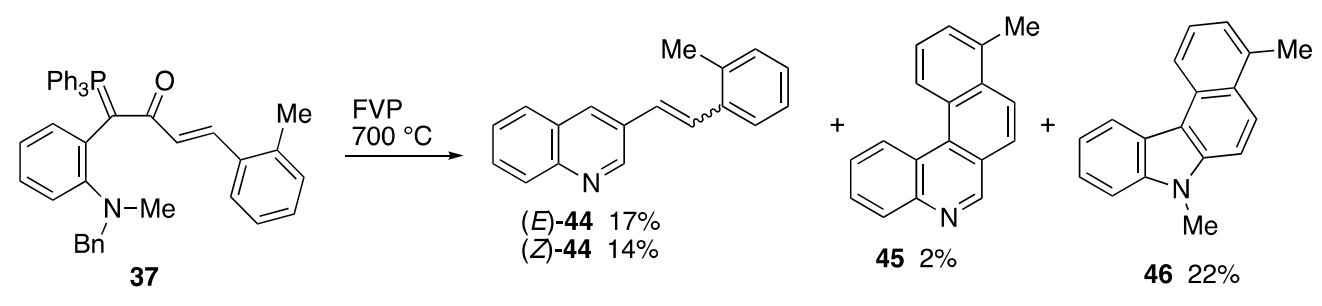

Scheme 8. FVP of ylide 37 to form 44-46.

As mentioned in the introduction, one reason for trying ylide 37 was that in earlier work we observed the involvement of an ortho-methyl group in such ylide pyrolyses to give naphthalenes $[16,17]$. This was not observed for 37 nor for the second methyl-containing ylide 38, which simply afforded the $(E)$ - and (Z)-thienylvinylquinolines 47, corresponding to 42 in low yield (Scheme 9). However, even in this case, the contrast with the behavior of the ylide 18 caused by introduction of the single methyl group remote from the reactive site for initial cyclization is remarkable.<smiles>Cc1ccsc1/C=C/C(=O)C(=P)c1ccccc1N(C)Cc1ccccc1</smiles>

38<smiles>Cc1ccsc1C=Cc1cnc2ccccc2c1</smiles>

Scheme 9. FVP of ylide 38 to form 47 .

\section{Experimental}

\subsection{General Experimental Details}

NMR spectra were recorded on solutions in $\mathrm{CDCl}_{3}$ using Bruker instruments, and chemical shifts are given in ppm to high frequency from $\mathrm{Me}_{4} \mathrm{Si}(\mathrm{H}, \mathrm{C})$ or $85 \% \mathrm{H}_{3} \mathrm{PO}_{4}(\mathrm{P})$ with coupling constants $J$ in $\mathrm{Hz}$. Both low- and high-resolution mass spectra were recorded using electrospray ionization. All chromatographic separation was carried out on silica gel.

Flash vacuum pyrolysis (FVP) was carried out in a conventional flow system by subliming the starting material through a horizontal quartz tube $(30 \times 2.5 \mathrm{~cm})$, externally heated by a tube furnace to $700{ }^{\circ} \mathrm{C}$ and maintained at a pressure of $2-3 \times 10^{-2}$ torr by a rotary vacuum pump. The apparatus used is illustrated, and a detailed experimental procedure is given in a recent publication [19]. Products were collected in a liquid $\mathrm{N}_{2}$-cooled, $\mathrm{U}$-shaped trap, and purified as noted. 
The phosphonium salt 39 was prepared as previously described [12]. The $\alpha, \beta$-unsaturated carboxylic acids were prepared from the corresponding aldehydes by a standard Doebner reaction with malonic acid in pyridine with catalytic piperidine.

\subsection{X-ray Structure Determination for $\mathbf{1 4}$}

The compound was prepared as previously reported [12] and recrystallized from ethyl acetate/diethyl ether (1:1) to give crystals suitable for X-ray diffraction.

Crystal data for $\mathrm{C}_{40} \mathrm{H}_{34} \mathrm{NO}_{3} \mathrm{PS}, M=639.71 \mathrm{~g} \cdot \mathrm{mol}^{-1}$, yellow prism, crystal dimensions $0.10 \times 0.10 \times 0.10 \mathrm{~mm}$, monoclinic, space group $P 2_{1} / \mathrm{n}, a=10.055(2), b=18.021(3), c=18.125(4)$ $\mathrm{A}, \beta=99.928(5)^{\circ}, V=3234.9(11) \mathrm{A}^{3}, \mathrm{Z}=4, D_{\text {calc }}=1.313 \mathrm{~g} \cdot \mathrm{cm}^{-3}, T=93(2) \mathrm{K}, R=0.033, R_{w}=0.079$ for 5185 reflections with $I>2 \sigma(I)$ and 418 variables. Data were collected using graphite-monochromated Mo $\mathrm{K} \alpha$ radiation $\lambda=0.71073 \mathrm{~A}$ and have been deposited at the Cambridge Crystallographic Data Centre as CCDC 1849881. The data can be obtained free of charge from the Cambridge Crystallographic Data Centre via www.ccdc.cam.ac.uk/getstructures.

\subsection{Preparation of N-Acylbenzotriazoles}

\subsubsection{1-(3-(3-Furyl)propenoyl)benzotriazole 31}

To a stirred solution of benzotriazole $(17.15 \mathrm{~g}, 143.9 \mathrm{mmol})$ in $\mathrm{CH}_{2} \mathrm{Cl}_{2}(200 \mathrm{~mL})$, thionyl chloride $(4.28 \mathrm{~g}, 2.61 \mathrm{~mL}, 35.9 \mathrm{mmol})$ was added dropwise. After stirring the resulting mixture for $30 \mathrm{~min}$, 3-(3-furyl)acrylic acid [20] (5.00 g, $35.9 \mathrm{mmol})$ was added and the mixture stirred at rt for a further $3 \mathrm{~h}$. The mixture was then filtered and the solid washed with $\mathrm{CH}_{2} \mathrm{Cl}_{2}$. The combined filtrate was washed with $2 \mathrm{M}$ aq. $\mathrm{NaOH}$ water, then brine. Drying and evaporation, followed by recrystallization of the residue $\left(\mathrm{CH}_{2} \mathrm{Cl}_{2}\right)$, gave $31(3.25 \mathrm{~g}, 38 \%)$ as colorless needles, m.p. $169-170{ }^{\circ} \mathrm{C}$. (Found: $\mathrm{M}^{+}+\mathrm{Na}$, 262.0598. $\mathrm{C}_{13} \mathrm{H}_{9} \mathrm{NaN}_{3} \mathrm{O}_{2}\left(\mathrm{M}^{+}+\mathrm{Na}\right)$ requires, 262.0592); $v_{\max } / \mathrm{cm}^{-1} 1703,1621(\mathrm{CO}), 1379,1151$ and 992; $\delta_{\mathrm{H}} 8.41(1 \mathrm{H}, \mathrm{d}, \mathrm{J} 8, \mathrm{H}-7), 8.15(1 \mathrm{H}, \mathrm{d}, \mathrm{J} 8, \mathrm{H}-4), 8.06(1 \mathrm{H}, \mathrm{d}, \mathrm{J} 16, \mathrm{COCH}=\mathrm{CH}), 7.87-7.79$ (2 H, m, $\mathrm{COCH}=\mathrm{CH}$, furyl-H), $7.68(1 \mathrm{H}, \mathrm{t}, \mathrm{J} 8, \mathrm{H}-5$ or 6$), 7.56-7.51(2 \mathrm{H}, \mathrm{m}, \mathrm{H}-5$ or 6 , furyl-H) and $6.83(1 \mathrm{H}$, d, J 2, H-4 of furyl); $\delta_{\mathrm{C}} 163.9$ (4ry, CO), $146.4(\mathrm{CH}), 146.2$ (4ry, C-3a of Bt), 144.8 (CH), 138.6 (C-2 of furyl), 131.4 (4ry, C-7a of Bt), $130.2(\mathrm{CH}), 126.1(\mathrm{CH}), 123.0$ (4ry, C-3 of furyl), $120.1(\mathrm{CH}), 115.7(\mathrm{CH})$, $114.7(\mathrm{CH})$, and 107.6 (C-4 of furyl); $m / z\left(\mathrm{ES}^{+}\right) 262.04\left(\mathrm{M}^{+}+\mathrm{Na}, 100 \%\right)$.

\subsubsection{1-(3-(3-Thienyl)propenoyl)benzotriazole 32}

This was prepared as in Section 3.3.1 using benzotriazole (15.25 g, $128.0 \mathrm{mmol})$, thionyl chloride (3.81 g, $2.32 \mathrm{~mL}, 32.4 \mathrm{mmol}$ ), and 3-(3-thienyl)acrylic acid (5.00 g, $32.4 \mathrm{mmol}$ ). Drying and evaporation, followed by recrystallization of the residue $\left(\mathrm{CH}_{2} \mathrm{Cl}_{2}\right)$, gave $32(5.30 \mathrm{~g}, 65 \%)$ as yellow needles, m.p. 154-156 ${ }^{\circ} \mathrm{C}$. (Found: $\mathrm{M}^{+}+\mathrm{Na}, 278.0370 . \mathrm{C}_{13} \mathrm{H}_{9} \mathrm{NaN}_{3} \mathrm{OS}\left(\mathrm{M}^{+}+\mathrm{Na}\right)$ requires, 278.0364$) ; v_{\mathrm{max}} / \mathrm{cm}^{-1}$ 1696 (CO), 1611, 1285, 1069, 993, 782 and 743; $\delta_{\mathrm{H}} 8.42(1 \mathrm{H}, \mathrm{dt}, J$ 8, 1, H-7), $8.15(1 \mathrm{H}, \mathrm{dt}, J$ 8, 1, H-4), $8.14(1 \mathrm{H}, \mathrm{d}, J$ 15, COCH=CH), $7.93(1 \mathrm{H}, \mathrm{d}, J$ 15, COCH=CH), $7.76(1 \mathrm{H}, \mathrm{dd}, J 3,1, \mathrm{H}-2$ of thienyl), $7.68(1 \mathrm{H}, \mathrm{td}, J$ 8, 1, H-5 or 6), $7.55(1 \mathrm{H}, \mathrm{dd}, J 5,1, \mathrm{H}-5$ of thienyl), $7.53(1 \mathrm{H}, \mathrm{td}, J$ 8, 1, H-5 or 6) and 7.43 (1 H, ddd, J 5, 3, 1, H-4 of thienyl); $\delta_{\mathrm{C}} 164.0$ (4ry, CO), 146.1 (4ry, C-3a of Bt), 141.7 (CH), 137.5 (4ry, C-7a of Bt), 131.3 (4ry, C-3 of thienyl), $130.7(\mathrm{CH}), 130.1(\mathrm{CH}), 127.3(\mathrm{CH}), 126.0(\mathrm{CH}), 125.4(\mathrm{CH})$, $120.0(\mathrm{CH}), 115.4(\mathrm{CH})$ and $114.7(\mathrm{CH}) ; m / z\left(\mathrm{ES}^{+}\right) 277.98\left(\mathrm{M}^{+}+\mathrm{Na}, 100 \%\right)$.

\subsubsection{1-(3-(2-Methylphenyl)propenoyl)benzotriazole 33}

This was prepared as in Section 3.3.1 using benzotriazole (14.69 $\mathrm{g}, 123.3 \mathrm{mmol})$, thionyl chloride (3.67 g, $2.24 \mathrm{~mL}, 30.8 \mathrm{mmol})$ and (E)-3-(2-methylphenyl)prop-2-enoic acid (5.00 g, $30.8 \mathrm{mmol})$. Drying and evaporation, followed by recrystallization of the residue $\left(\mathrm{CH}_{2} \mathrm{Cl}_{2}\right)$, gave $33(1.77 \mathrm{~g}, 22 \%)$ as a white powder, m.p. $124-125^{\circ} \mathrm{C}$ (Lit. [21] 127-129 $\left.{ }^{\circ} \mathrm{C}\right) ; \delta_{\mathrm{H}} 8.47(1 \mathrm{H}, \mathrm{d}, \mathrm{J} 15, \mathrm{COCH}=\mathrm{CH}), 8.42(1 \mathrm{H}, \mathrm{dt}$, $J$ 8, 1, H-4 or 7 of Bt), $8.16(1 \mathrm{H}, \mathrm{dt}, J$ 8, 1, H-4 or 7 of Bt), $8.07(1 \mathrm{H}, \mathrm{d}, J 15, \mathrm{COCH}=\mathrm{CH}), 7.86(1 \mathrm{H}, \mathrm{d}, J$ 8), 
$7.69(1 \mathrm{H}, \mathrm{ddd}, J 8,7,1, \mathrm{H}-5$ or 6 of Bt), $7.54(1 \mathrm{H}, \mathrm{ddd}, J$ 8, 7, 1, H-5 or 6 of Bt), 7.40-7.27 (3 H, m) and $2.56(3 \mathrm{H}, \mathrm{s}, \mathrm{Me})$.

\subsubsection{1-(3-(3-Methyl-2-thienyl)propenoyl)benzotriazole 34}

This was prepared as in Section 3.3.1 using benzotriazole $(14.16 \mathrm{~g}, 118.9 \mathrm{mmol})$, thionyl chloride (3.53 g, $2.16 \mathrm{~mL}, 79.7 \mathrm{mmol}$ ), and (E)-3-(3-methyl-2-thienyl)prop-2-enoic acid (5.00 g, $29.7 \mathrm{mmol})$. Drying and evaporation, followed by recrystallization of the residue $\left(\mathrm{CH}_{2} \mathrm{Cl}_{2}\right)$, gave $34(4.20 \mathrm{~g}, 60 \%)$ as pale yellow powder, m.p. $169-170{ }^{\circ} \mathrm{C}$. (Found: $\mathrm{M}^{+}+\mathrm{Na}$, 292.0521. $\mathrm{C}_{14} \mathrm{H}_{11} \mathrm{NaN}_{3} \mathrm{OS}\left(\mathrm{M}^{+}+\mathrm{Na}\right)$ requires, 292.0521); $v_{\max } / \mathrm{cm}^{-1} 1699(\mathrm{CO}), 1601,1380,1278$ and $988 ; \delta_{\mathrm{H}} 8.39(1 \mathrm{H}, \mathrm{dt}, J 8,1, \mathrm{H}-4$ or 7 of $\mathrm{Bt}), 8.32(1 \mathrm{H}, \mathrm{dd}, J$ 16, 1, COCH=CH), $8.14(1 \mathrm{H}, \mathrm{dt}, J$ 8, 1, H-4 or 7 of Bt), $7.80(1 \mathrm{H}, \mathrm{d}, J$ 16, COCH=CH), $7.67(1 \mathrm{H}, \mathrm{ddd}, J$ 8, 7, 1, H-5 or 6 of Bt), $7.52(1 \mathrm{H}, \mathrm{ddd}, J$ 8, 7, 1, H-5 or 6 of Bt), $7.42(1 \mathrm{H}, \mathrm{br} \mathrm{d}, J 5), 6.94$ $(1 \mathrm{H}, \mathrm{dd}, J 5,0.3)$ and $2.46(3 \mathrm{H}, \mathrm{s}, \mathrm{Me}) ; \delta_{\mathrm{C}} 169.9$ (4ry, CO), 146.2 (4ry), 144.0 (2C, 4ry), $139.2(\mathrm{CH}), 134.0$ (4ry), $131.4(\mathrm{CH}), 130.1(\mathrm{CH}), 129.2(\mathrm{CH}), 126.0(\mathrm{CH}), 120.1(\mathrm{CH}), 114.7(\mathrm{CH}), 113.2(\mathrm{CH})$, and $14.4\left(\mathrm{CH}_{3}\right)$; $m / z\left(\mathrm{ES}^{+}\right) 292.01\left(\mathrm{M}^{+}+\mathrm{Na}, 100 \%\right)$.

\subsection{Preparation of Ylides}

\subsection{1. [(2-(N-Methyl-N-benzylamino)phenyl)(3-(3-furyl)propenoyl)methylene]triphenylphosphorane 35}

A suspension of the phosphonium salt $39(2.00 \mathrm{~g}, 3.62 \mathrm{mmol})$ in dry THF $(10 \mathrm{~mL})$ was stirred under nitrogen while a solution of butyllithium in hexanes $\left(1.60 \mathrm{~cm}^{3}, 2.25 \mathrm{M}, 3.62 \mathrm{mmol}\right)$ was added. The resulting red solution of 40 was stirred at $\mathrm{rt}$ for $2 \mathrm{~h}$, after which a solution of the $\mathrm{N}$-acylbenzotriazole $31(0.86 \mathrm{~g}, 3.62 \mathrm{mmol})$ in THF $(5 \mathrm{~mL})$ was added and the mixture stirred for a further $18 \mathrm{~h}$. Water $(20 \mathrm{~mL})$ was then added, and the resulting mixture extracted with ethyl acetate $(2 \times 20 \mathrm{~mL})$. The combined extracts were washed with water, dried, and evaporated. The resulting solid was recrystallized ( $\left.\mathrm{Et}_{2} \mathrm{O} / \mathrm{EtOAc}\right)$ to give $35(0.89 \mathrm{~g}, 41 \%)$ as yellow crystals, m.p. $184-185^{\circ} \mathrm{C}$; (Found: $\mathrm{M}^{+}+\mathrm{H}, 592.2411$. $\mathrm{C}_{40} \mathrm{H}_{35} \mathrm{NO}_{2} \mathrm{P}\left(\mathrm{M}^{+}+\mathrm{H}\right)$, requires 592.2405); $v_{\max } / \mathrm{cm}^{-1} 1633,1434,1105,970,748$ and $692 ; \delta_{\mathrm{H}} 7.87-7.27$ $(15 \mathrm{H}, \mathrm{m}), 7.21-7.09(6 \mathrm{H}, \mathrm{m}), 7.07-6.79(7 \mathrm{H}, \mathrm{m}), 6.40(1 \mathrm{H}, \mathrm{d}, J$ 8, H-3 of Ar), $4.45(1 \mathrm{H}, \mathrm{d}, J$ 14, CHHPh), $3.75(1 \mathrm{H}, \mathrm{d}, J \mathrm{~J} 14, \mathrm{CHHPh})$ and $2.10(3 \mathrm{H}, \mathrm{s}, \mathrm{Me}) ; \delta_{\mathrm{C}}\left(+55^{\circ} \mathrm{C}\right) 178.9(\mathrm{~d}, J 6, \mathrm{C}=\mathrm{O}), 154.1(\mathrm{~d}, J$ 4, ArC-N), 143.3 (furyl C-O), 142.7 (furyl C-O), 138.4 (d, J 5, CH), 136.9 (C), 133.8 (d, J 10, C-2 of PPh), 131.8 (d, J 10, $\mathrm{P}=\mathrm{C}-\mathrm{C}), 131.4(\mathrm{~d}, J$ 2, C-4 of PPh), 129.5 (2CH), 128.3 (d, J 12, C-3 of PPh), $127.8(2 \mathrm{CH}), 127.7$ (d, J 3), $126.9(\mathrm{CH}), 126.7$ (d, J 91, C-1 of PPh), $126.3(\mathrm{~d}, J$ 12, CH), $124.7(\mathrm{CH}), 124.1$ (furyl C-3), 122.8 (d, J 2, $\mathrm{CH}), 121.3\left(\mathrm{~d}, J\right.$ 2, CH), 107.9 (furyl C-4), $75.3\left(\mathrm{~d}, J\right.$ 107, P=C), $60.1\left(\mathrm{CH}_{2}\right)$, and $39.6(\mathrm{NMe}) ; \delta_{\mathrm{P}}+15.3$; $m / z\left(\mathrm{ES}^{+}\right) 592.09\left(\mathrm{M}^{+}+\mathrm{H}, 100 \%\right)$.

\subsection{2. [(2-(N-Methyl-N-benzylamino)phenyl)(3-(3-thienyl)propenoyl)methylene]triphenylphosphorane 36}

This was prepared as in Section 3.4.1 using salt 39 (1.35 g, $2.44 \mathrm{mmol})$, a solution of butyllithium $\left(1.08 \mathrm{~cm}^{3}, 2.25 \mathrm{M}, 2.44 \mathrm{mmol}\right)$ and $\mathrm{N}$-acylbenzotriazole $32(0.55 \mathrm{~g}, 2.44 \mathrm{mmol})$. The resulting solid was recrystallized $\left(\mathrm{Et}_{2} \mathrm{O} / \mathrm{EtOAc}\right)$ to give $36(0.51 \mathrm{~g}, 35 \%)$ as orange crystals, m.p. $178-180{ }^{\circ} \mathrm{C}$. (HMRS: found $\mathrm{M}^{+}+\mathrm{H}, 608.2175$. $\mathrm{C}_{40} \mathrm{H}_{35} \mathrm{NOPS}\left(\mathrm{M}^{+}+\mathrm{H}\right)$ requires, 608.2177); $v_{\max } / \mathrm{cm}^{-1} 1624,1492,1197,1101$, 750 and $691 ; \delta_{\mathrm{H}}\left(+55^{\circ} \mathrm{C}\right) 7.68-7.54(8 \mathrm{H}, \mathrm{m}), 7.45-7.33(5 \mathrm{H}, \mathrm{m}), 7.30-7.21(4 \mathrm{H}, \mathrm{m}), 7.19-7.11(5 \mathrm{H}, \mathrm{m})$, 7.09-7.02 (2 H, m), 6.99-6.89 (4 H, m), 6.52 (1 H, d, J 8), 4.40 (1 H, d, J 14, CHHPh), 3.84 (1 H, d, J 14, CHHPh) and $2.19(3 \mathrm{H}, \mathrm{s}, \mathrm{Me}) ; \delta_{\mathrm{C}}\left(+55^{\circ} \mathrm{C}\right) 179.1(\mathrm{~d}, J 5, \mathrm{C}=\mathrm{O}), 154.2(\mathrm{~d}, J$ 4 , ArC-N), 139.8 (thienyl C-3), 138.4 (d, J 5, CH), 137.0 (C), 133.8 (d, J 10, C-2 of PPh), 131.8 (d, J 10, P=C-C), 131.4 (d, J 3, C-4 of PPh), $129.5(2 \mathrm{CH}), 129.1$ (d, J 1, CH), 128.3 (d, J 12, C-3 of PPh), $127.8(2 \mathrm{CH}), 127.8$ (d, J 3), 126.9 (CH), 126.7 (d, J 91, C-1 of PPh), $126.4(\mathrm{~d}, J$ 12, CH), $126.0(\mathrm{CH}), 125.6(\mathrm{CH}), 124.6(\mathrm{CH}), 122.8(\mathrm{~d}, J$ 2, CH), $121.3(\mathrm{~d}$, $J$ 2, CH), $75.7(\mathrm{~d}, J$ 108, $\mathrm{P}=\mathrm{C}), 60.1\left(\mathrm{CH}_{2}\right)$, and $39.6(\mathrm{NMe}) ; \delta_{\mathrm{P}}+15.3 ; \mathrm{m} / z\left(\mathrm{ES}^{+}\right) 608.01\left(\mathrm{M}^{+}+\mathrm{H}, 100 \%\right)$. 
3.4.3. [(2-(N-Methyl-N-benzylamino)phenyl)(3-(2-methyl)phenylpropenoyl)methylene]tripheny lphosphorane 37

This was prepared as in Section 3.4.1 using salt $39(1.00 \mathrm{~g}, 1.81 \mathrm{mmol})$, a solution of butyllithium in hexanes $(0.89 \mathrm{~mL}, 2.04 \mathrm{M}, 1.81 \mathrm{mmol})$ and $\mathrm{N}$-acylbenzotriazole $33(0.48 \mathrm{~g}, 1.81 \mathrm{mmol})$. Recrystallization of the residue (diethyl ether/EtOAc) gave the title product $37(0.55 \mathrm{~g}, 50 \%)$ as yellow crystals, m.p. 207-208 ${ }^{\circ} \mathrm{C}$. (Found: $\mathrm{M}^{+}+\mathrm{H}, 616.2753$. $\mathrm{C}_{43} \mathrm{H}_{39} \mathrm{NOP}\left(\mathrm{M}^{+}+\mathrm{H}\right)$ requires, 616.2769); $v_{\max } / \mathrm{cm}^{-1} 1634,1433,1172,1086,710$ and $677 ; \delta_{\mathrm{H}} 7.75(1 \mathrm{H}, \mathrm{d}, J 15, \mathrm{CH}=\mathrm{CH}), 7.70-7.59(5 \mathrm{H}, \mathrm{br} \mathrm{s})$, 7.51-7.31 (11 H, m), 7.24-7.16 (3 H, m), 7.12-6.93 (9 H, m), $6.55(1 \mathrm{H}, \mathrm{d}, J$ J , H-3 of Ar), $4.51(1 \mathrm{H}, \mathrm{d}, J$ 14, CHHPh), $3.85(1 \mathrm{H}, \mathrm{d}, J 14, \mathrm{CHHPh}), 2.39(3 \mathrm{H}, \mathrm{s}, \mathrm{Me})$ and $2.24(3 \mathrm{H}, \mathrm{s}, \mathrm{Me}) ; \delta_{\mathrm{C}}\left(+55^{\circ} \mathrm{C}\right) 179.7(\mathrm{~d}, J 7$, $\mathrm{C}=\mathrm{O}), 154.3(\mathrm{~d}, J$ 4, $\mathrm{ArC}-\mathrm{N}), 138.8(\mathrm{~d}, J$ 5 , CH), $137.3(\mathrm{C}), 137.0$ (C), $136.3(\mathrm{C}), 133.8$ (d, J 10, C-2 of PPh), $132.3(\mathrm{~d}, J$ 10, P=C-C), $132.2(\mathrm{CH}), 131.1(\mathrm{~d}, J$ 3, C-4 of PPh), $130.3(\mathrm{CH}), 129.5(2 \mathrm{CH}), 128.5(\mathrm{~d}, J$ 12, CH), 128.4 (CH), 128.2 (d, J 12, C-3 of PPh), $127.8(2 \mathrm{CH}), 127.6(\mathrm{CH}), 127.4(\mathrm{~d}, J$ 90, C-1 of PPh), $126.8(\mathrm{CH})$, $126.3(\mathrm{CH}), 125.7(\mathrm{CH}), 122.6\left(\mathrm{~d}, J\right.$ 2, CH), $121.0\left(\mathrm{~d}, J\right.$ 2, CH), $72.8(\mathrm{~d}, J$ 109, $\mathrm{P}=\mathrm{C}), 60.0\left(\mathrm{CH}_{2}\right), 39.5(\mathrm{NMe})$, and $20.0(\mathrm{Me}) ; \delta_{\mathrm{P}}+15.4 ; m / z\left(\mathrm{ES}^{+}\right) 616.08\left(\mathrm{M}^{+}+\mathrm{H}, 100 \%\right)$.

3.4.4. [(2-(N-Methyl-N-benzylamino)phenyl)(3-(3-methyl-2-thienyl)propenoyl)methylene]triphenyl phosphorane 38

This was prepared as in Section 3.4.1 using salt $39(1.00 \mathrm{~g}, 1.81 \mathrm{mmol})$, a solution of butyllithium in hexanes $(0.89 \mathrm{~mL}, 2.04 \mathrm{M}, 1.81 \mathrm{mmol})$ and $\mathrm{N}$-acylbenzotriazole $34(0.49 \mathrm{~g}, 1.81 \mathrm{mmol})$. The resulting solid was recrystallized $\left(\mathrm{Et}_{2} \mathrm{O} / \mathrm{EtOAc}\right)$ to give the title product $38(0.55 \mathrm{~g}, 49 \%)$ as orange crystals, m.p. 197-198 ${ }^{\circ} \mathrm{C}$. (Found: $\mathrm{M}^{+}+\mathrm{H}, 622.2347 . \mathrm{C}_{41} \mathrm{H}_{37} \mathrm{NOPS}\left(\mathrm{M}^{+}+\mathrm{H}\right)$ requires, 622.2333); $v_{\max } / \mathrm{cm}^{-1} 1720,1605$, $1196,1094,719$ and $686 ; \delta_{\mathrm{H}}\left(+55^{\circ} \mathrm{C}\right) 7.71-7.51(7 \mathrm{H}, \mathrm{br} \mathrm{m}), 7.48-7.27(10 \mathrm{H}, \mathrm{m}), 7.19-7.14(3 \mathrm{H}, \mathrm{m}), 7.05-6.88$ $(5 \mathrm{H}, \mathrm{m}), 6.81(1 \mathrm{H}, \mathrm{d}, J$ 15, P=C), $6.70(1 \mathrm{H}, \mathrm{d}, J$ 5 ), $6.44(1 \mathrm{H}, \mathrm{d}, J$ 8, C-3 of Ar), $4.45(1 \mathrm{H}, \mathrm{d}, J$ 14, CHHPh), $3.72(1 \mathrm{H}, \mathrm{d}, J 14, \mathrm{CHHPh}), 2.22(3 \mathrm{H}, \mathrm{s}, \mathrm{Me})$ and $2.15(3 \mathrm{H}, \mathrm{s}, \mathrm{Me}) ; \delta_{\mathrm{C}}\left(+55^{\circ} \mathrm{C}\right) 179.1(\mathrm{~d}, J 6, \mathrm{C}=\mathrm{O}), 153.9(\mathrm{~d}$, J 4, ArC-N), 138.5 (d, J 5, CH), 136.8 (C), 136.5 (d, J 1, C), 133.8 (d, J 10, C-2 of PPh), 132.1 (d, J 10, P=C-C), 131.2 (d, J 2, C-4 of PPh), $130.7(\mathrm{CH}), 129.8(2 \mathrm{CH}), 128.4(\mathrm{~d}, J$ 12, CH), $128.2(\mathrm{~d}, J$ 12, C-3 of PPh), $127.7(2 \mathrm{CH})$, $127.4(\mathrm{~d}, J$ 2), $127.2(\mathrm{~d}, J$ 92, C-1 of PPh), $126.7(\mathrm{CH}), 126.1(\mathrm{~d}, J$ 1, CH), $126.0(\mathrm{C}), 123.6(\mathrm{CH}), 122.6(\mathrm{CH})$, $121.3(\mathrm{~d}, J 2, \mathrm{CH}), 72.9(\mathrm{~d}, J 108, \mathrm{P}=\mathrm{C}), 60.0\left(\mathrm{CH}_{2}\right), 39.3(\mathrm{NMe})$, and $14.0(\mathrm{Me}) ; \delta_{\mathrm{P}}+15.7 ; \mathrm{m} / z\left(\mathrm{ES}^{+}\right) 622.03$ $\left(\mathrm{M}^{+}+\mathrm{H}, 100 \%\right)$.

\subsection{Flash Vacuum Pyrolysis of Ylides}

\subsubsection{FVP of Ylide 35}

Ylide $35(0.3234 \mathrm{~g}, 0.54 \mathrm{mmol})$ was subjected to FVP at $700{ }^{\circ} \mathrm{C}$ and $2-3 \times 10^{-2}$ torr. NMR analysis of the crude product showed a mixture of $\mathrm{Ph}_{3} \mathrm{PO}$, bibenzyl, and other products. Separation by column chromatography (9:1 diethyl ether:hexane) followed by preparative TLC (60:40 diethyl ether:hexane) gave 9-methylphenanthridine $41(0.031 \mathrm{~g}, 30 \%), \delta_{\mathrm{H}} 9.25(1 \mathrm{H}, \mathrm{s}, \mathrm{H}-6), 8.59(1 \mathrm{H}$, ddd, J 8, 1, 0.4, H-1), $8.42(1 \mathrm{H}, \mathrm{d}, J$ J, $\mathrm{H}-10), 8.20(1 \mathrm{H}, \mathrm{dd}, J$ 8, 1, H-8), $8.00(1 \mathrm{H}, \mathrm{d}, J$ 8, H-7), $7.75(1 \mathrm{H}, \mathrm{tdd}, J$ 8, 1, 0.4, H-2 or 3), $7.68\left(1 \mathrm{H}, \mathrm{tdd}, J 8,1,0.4, \mathrm{H}-2\right.$ or 3), $7.56(1 \mathrm{H}, \mathrm{ddd}, J 8,1,0.4, \mathrm{H}-4)$ and $2.68(3 \mathrm{H}, \mathrm{ArMe})$ [Lit. [22] $\delta_{\mathrm{H}}$ (DMSO) $9.05(1 \mathrm{H}, \mathrm{s}), 8.28(1 \mathrm{H}, \mathrm{dd}, J$ 8.2, 1.3), $8.12(1 \mathrm{H}, \mathrm{dd}, J$ 8.1, 1.2), 7.64-7.58 (2 H, m), 7.52-7.46 $(1 \mathrm{H}, \mathrm{m}), 7.23(1 \mathrm{H}, \mathrm{dd}, J$ 8.1, 1.2), and $2.41(3 \mathrm{H}, \mathrm{s}).] ; m / z\left(\mathrm{ES}^{+}\right) 194.09\left(\mathrm{M}^{+}+\mathrm{H}, 10 \%\right)$.

\subsubsection{FVP of Ylide 36}

Ylide 36 (0.2147 g, $0.35 \mathrm{mmol})$ was subjected to FVP at $700{ }^{\circ} \mathrm{C}$ and $2-3 \times 10^{-2}$ torr. NMR analysis of the crude product showed a mixture of $\mathrm{Ph}_{3} \mathrm{PO}$, bibenzyl, and other products. The mixture was separated by column chromatography (60:40 diethyl ether:hexane) giving 3-(2-(3-thienyl)ethenyl)quinoline 42 ( $E, 0.0235 \mathrm{~g}, 28 \%$. Z, $0.0126 \mathrm{~g}, 15 \%$ ); (Found: $\mathrm{M}^{+}+\mathrm{H}, 238.0689$. $\mathrm{C}_{15} \mathrm{H}_{12} \mathrm{NS}\left(\mathrm{M}^{+}+\mathrm{H}\right)$ requires, 238.0690); $\delta_{\mathrm{H}}(E) 9.09(1 \mathrm{H}, \mathrm{d}, \mathrm{J} 2, \mathrm{H}-2), 8.14(1 \mathrm{H}, \mathrm{d}, J 2, \mathrm{H}-4), 8.09(1 \mathrm{H}, \mathrm{ddd}$, $J ~ 8,1.2,0.6, \mathrm{H}-8), 7.81(1 \mathrm{H}, \mathrm{ddd}, J 8,1.2,0.6, \mathrm{H}-5), 7.67(1 \mathrm{H}, \mathrm{ddd}, J 8,7,1.2, \mathrm{H}-6$ or 7$), 7.54(1 \mathrm{H}, \mathrm{ddd}, J 8$, 7, 1.2, $\mathrm{H}-6$ or 7), $7.43\left(1 \mathrm{H}, \mathrm{m}, \mathrm{H}-4^{\prime}\right), 7.38-7.35\left(2 \mathrm{H}, \mathrm{m}, \mathrm{H}-2^{\prime}\right.$ and $\left.5^{\prime}\right)$, and 7.35 and $7.09(2 \mathrm{H}, \mathrm{AB}$ pattern, 
$J$ 16, H-a and b); $\delta_{\mathrm{H}}(\mathrm{Z}) 8.82(1 \mathrm{H}, \mathrm{d}, J-2, \mathrm{H}-2), 8.05(1 \mathrm{H}, \mathrm{d}, J$ 2, H-4), $8.07(1 \mathrm{H}, \mathrm{ddd}, J$ 8, 1.2, 0.6, H-8), $7.73(1 \mathrm{H}, \mathrm{ddd}, J$ 8, 1.2, 0.6, H-5), $7.69(1 \mathrm{H}, \mathrm{ddd}, J$ 8, 6, 1.2, H-6 or 7), $7.53(1 \mathrm{H}, \mathrm{ddd}, J$ 8, 7, 1.2, H-6 or 7), 7.18-7.15 (2 H, m, H-2' and $\left.5^{\prime}\right), 6.86\left(1 \mathrm{H}, \mathrm{ddd}, J 3,2.5,1, \mathrm{H}-4^{\prime}\right)$ and 6.76 and $6.65(2 \mathrm{H}, \mathrm{AB}$ pattern, $J 12$, $\mathrm{H}-\mathrm{a}$ and $\mathrm{b}) ; m / z\left(\mathrm{ES}^{+}\right) 238.01\left(\mathrm{M}^{+}+\mathrm{H}, 100 \%\right)$. Also obtained was thieno[3,2-k]phenanthridine 43 $(0.0066 \mathrm{~g}, 8 \%)$; (Found: $\mathrm{M}^{+}+\mathrm{H}, 236.0535 . \mathrm{C}_{15} \mathrm{H}_{10} \mathrm{NS}\left(\mathrm{M}^{+}+\mathrm{H}\right)$ requires 236.0534); $\delta_{\mathrm{H}} 9.46(1 \mathrm{H}, \mathrm{s}, \mathrm{H}-6)$, 9.09 (1 H, ddd, J 9.2, 1.2, 0.8, H-11), 8.39 (1 H, ddd, J 9.2, 1.2, 0.8, H-8), 8.22 (1 H, d, J 8, H-4 or 5), 8.08 $(1 \mathrm{H}, \mathrm{d}, J$ 8, H-4 or 5), $7.91(1 \mathrm{H}, \mathrm{d}, J 5.6, \mathrm{H}-2$ or 3$), 7.90(1 \mathrm{H}, \mathrm{ddd}, J 9.2,7.6,1.2, \mathrm{H}-9$ or 10$), 7.88(1 \mathrm{H}$, ddd, J 9.2, 7.6, 1.2, H-9 or 10), and $7.71\left(1 \mathrm{H}, \mathrm{d}, J 5.6, \mathrm{H}-2\right.$ or 3); $m / z\left(\mathrm{ES}^{+}\right) 236.04\left(\mathrm{M}^{+}+\mathrm{H}, 100 \%\right)$.

\subsubsection{FVP of Ylide 37}

Ylide $37(0.1971 \mathrm{~g}, 0.32 \mathrm{mmol})$ was subjected to FVP at $700{ }^{\circ} \mathrm{C}$ and $2-3 \times 10^{-2}$ torr. NMR analysis of the crude product showed a mixture of $\mathrm{Ph}_{3} \mathrm{PO}$, bibenzyl, and other products. The mixture was roughly separated into two fractions by column chromatography (50:50 diethyl ether:hexane). The first fraction was purified by preparative TLC (10:90 diethyl ether:hexane) to give 4,7-dimethylbenzo[c]carbazole 46 (0.0179 g, 22\%); (Found: $\mathrm{M}^{+}+\mathrm{H}, 246.1279 . \mathrm{C}_{18} \mathrm{H}_{16} \mathrm{~N}\left(\mathrm{M}^{+}+\mathrm{H}\right)$ requires, 246.1283); $\delta_{\mathrm{H}} 8.71(1 \mathrm{H}, \mathrm{ddd}$, J 8.4, 0.8, 0.5, H-1), 8.605 (1 H, ddd, J 8, 1.2, 0.5, H-11), $8.119(1 \mathrm{H}, \mathrm{dd}, J$ 9.2, 0.5, H-5), $7.696(1 \mathrm{H}, \mathrm{d}, J$ J 9.2, H-6), 7.602 (1 H, dd, J 8.4, 6.8, H-2), $7.562(1 \mathrm{H}, \mathrm{ddd}, J$ 8, 1.2, 0.5, H-8), $7.515(1 \mathrm{H}$, ddd, J 8, 7.2, 1.2, H-9), $7.385(1 \mathrm{H}, \mathrm{ddd}, J$ 8, 7.2, 1.2, H-10), $7.324(1 \mathrm{H}, \mathrm{dd}, J$ 6.8, 0.8, H-3), $4.00(3 \mathrm{H}, \mathrm{s}, \mathrm{NMe})$ and $2.82(3 \mathrm{H}, \mathrm{s}$, ArMe); $\delta_{\mathrm{C}} 130.1$ (4ry), $126.5(\mathrm{CH}), 124.1(\mathrm{CH}), 124.0(\mathrm{CH}), 123.1(\mathrm{CH}), 122.2(\mathrm{CH}), 121.6(\mathrm{CH}), 120.9$ (4ry), 120.3 (4ry), 119.6 (CH), 115.6 (4ry), 114.6 (4ry), 113.9 (4ry), $110.0(\mathrm{CH}), 109.0(\mathrm{CH}), 29.3$ (NMe) and $20.4(\mathrm{ArMe}) ; \mathrm{m} / \mathrm{z}\left(\mathrm{ES}^{+}\right) 246.08\left(\mathrm{M}^{+}+\mathrm{H}, 100 \%\right)$. The second fraction was purified by preparative TLC (10:90 diethyl ether:hexane) to give 3-(2-(2-methylphenyl)ethenyl)quinoline $44(E, 0.0134 \mathrm{~g}, 17 \%$. $\mathrm{Z}, 0.0101 \mathrm{~g}, 14 \%)$; (Found: $\mathrm{M}^{+}+\mathrm{H}, 246.1291 . \mathrm{C}_{18} \mathrm{H}_{16} \mathrm{~N}\left(\mathrm{M}^{+}+\mathrm{H}\right)$ requires, 246.1283); $\delta_{\mathrm{H}}(E) 9.13(1 \mathrm{H}, \mathrm{d}$, $J$ 2, H-2), $8.18(1 \mathrm{H}, \mathrm{d}, J 2, \mathrm{H}-4), 8.10(1 \mathrm{H}, \mathrm{d}, J$ 8, H-5 or 8), $7.84(1 \mathrm{H}, \mathrm{dd}, J$ 8, 1, H-5 or 8), $7.69(1 \mathrm{H}, \mathrm{ddd}$, $J$ 8, 7, 1, H-6 or 7), $7.66(1 \mathrm{H}, \mathrm{d}, J$ 8), $7.56(1 \mathrm{H}$, half of $\mathrm{AB}$ pattern, $J 16, \mathrm{H}-\mathrm{a}$ or b), $7.55(1 \mathrm{H}$, ddd, $J$ 8, 7, 1, H-6 or 7), 7.29-7.20 $(3 \mathrm{H}, \mathrm{m}), 7.15\left(1 \mathrm{H}\right.$, half of $\mathrm{AB}$ pattern, $J 16, \mathrm{H}-\mathrm{a}$ or b) and $2.49(3 \mathrm{H}, \mathrm{s}, \mathrm{Me}) ; \delta_{\mathrm{H}}(\mathrm{Z})$ $8.62(1 \mathrm{H}, \mathrm{d}, J$ 2, H-2), $8.09(1 \mathrm{H}, \mathrm{d}, J$ 8, H-5 or 6), $7.84(1 \mathrm{H}, \mathrm{d}, J$ 2, H-4), $7.63(1 \mathrm{H}$, ddd, J 8, 6.5, 1, H-6 or 7), $7.61(1 \mathrm{H}, \mathrm{d}, J$ 8), $7.46(1 \mathrm{H}, \mathrm{ddd}, J 8,6.5,1, \mathrm{H}-6$ or 7$), 7.19(1 \mathrm{H}, \mathrm{br} \mathrm{t}, J 7.5), 7.12(1 \mathrm{H}, \mathrm{d}, J$ 8), 7.04 $(1 \mathrm{H}, \mathrm{br} \mathrm{t}, J 7.5), 6.89$ and $6.75\left(2 \mathrm{H}, \mathrm{AB}\right.$ pattern, $J 12, \mathrm{H}-\mathrm{a}$ and b) and $2.32(3 \mathrm{H}, \mathrm{s}, \mathrm{Me}) ; m / z\left(\mathrm{ES}^{+}\right) 246.00$ $\left(\mathrm{M}^{+}+\mathrm{H}, 100 \%\right)$. Also isolated from the same preparative TLC was 9-methylbenzo[ $\left.k\right]$ phenanthridine 45 (0.0017 g, 2\%), (Found: $\mathrm{M}^{+}+\mathrm{H}, 244.1120 . \mathrm{C}_{18} \mathrm{H}_{15} \mathrm{~N}\left(\mathrm{M}^{+}+\mathrm{H}\right)$ requires, 244.1126); $\delta_{\mathrm{H}} 9.37(1 \mathrm{H}, \mathrm{s}$, H-6), $9.07(2 \mathrm{H}, \mathrm{t}, J$ 8, H-1 and 12), $8.38(1 \mathrm{H}, \mathrm{dd}, J$ 8, 2, H-4), $8.25(1 \mathrm{H}, \mathrm{d}, J$ 9, H-8), $8.00(1 \mathrm{H}, \mathrm{d}, J$ 9, H-7), $7.81(1 \mathrm{H}, \mathrm{ddd}, J$ 8, 7, 1, H-2 or 3), $7.74(1 \mathrm{H}, \mathrm{ddd}, J 8,7,1, \mathrm{H}-2$ or 3$), 7.67(1 \mathrm{H}, \mathrm{t}, J$ 7, H-11), $7.59(1 \mathrm{H}, \mathrm{d}$, $J$ 7, $\mathrm{H}-10)$, and $2.87(3 \mathrm{H}, \mathrm{s}, \mathrm{Me}) ; m / z\left(\mathrm{ES}^{+}\right) 244.03\left(\mathrm{M}^{+}+\mathrm{H}, 100 \%\right)$.

\subsubsection{FVP of Ylide 38}

Ylide 38 (0.1072 g, $0.17 \mathrm{mmol})$ was subjected to FVP at $700{ }^{\circ} \mathrm{C}$ and $2-3 \times 10^{-2}$ torr. NMR analysis of the crude product showed a mixture of $\mathrm{Ph}_{3} \mathrm{PO}$, bibenzyl, and other products. The mixture was purified by column chromatography (50:50 diethyl ether:hexane) followed by preparative TLC (30:70 diethyl ether:hexane) to give a low yield of what appeared to be impure 3-(2-(3-methyl-2-thienyl)ethenyl)quinoline 47 as a dark brown oil. Indicative peaks at $\delta_{\mathrm{H}} 9.09(1 \mathrm{H}, \mathrm{d}$, $J$ 2, H-2 E), $8.83(1 \mathrm{H}, \mathrm{d}, J$ 2, H-2 Z), 2.39 ( $3 \mathrm{H}, \mathrm{s}$, ArMe $E$ or Z), and $2.20(3 \mathrm{H}, \mathrm{s}, \mathrm{ArMe}, E$ or Z) indicated a 1:1 mixture of $E / Z$-however, further purification and analysis was not possible.

\section{Conclusions}

The results from FVP of these four ylides further emphasize the sensitivity of the outcome in these reactions on the precise combination of substituents present. As compared to the previously studied $N$-benzyl- $N$-methylamino ylides, the present compounds show an almost complete change from carbazole products derived from cyclization of $\mathrm{N}(\mathrm{Me})^{\cdot}$ to quinoline and phenanthridine products derived from hydrogen atom transfer and cyclization of the resulting $\mathrm{NHCH}_{2}$. The results are more 
similar to those obtained from certain $N, N$-dibenzyl ylides, but even then, significant differences in product distribution are caused by the slightest change in ylide structure. The difference in pyrolysis outcome between the isomeric compounds $\mathbf{3 5}$ and $\mathbf{3 6}$ and $\mathbf{1 7}$ and $\mathbf{1 8}$ is striking, as is the effect of adding a single methyl substituent remote from the reactive site, as seen going from $\mathbf{1 6}$ to 37 or from 18 to 38 . We conclude that, as also found in our recent synthesis of Eustifoline D using this method [13], model studies are of little value in this area, and which pyrolytic routes will predominate in a given case can only be determined by experimentation.

Supplementary Materials: The following are available online. Figures S1-S27: NMR spectra of new compounds. Cif and check-cif files for X-ray structure of $\mathbf{1 4 .}$

Author Contributions: L.M. performed the experiments; A.M.Z.S. collected the X-ray data and solved the structure; R.A.A. designed the experiments, analyzed the data and wrote the paper.

Funding: We thank EPSRC (UK) for a DTA studentship (Grant No. EP/P501768/1).

Conflicts of Interest: The authors declare no conflict of interest.

\section{References}

1. Wentrup, C. Flash vacuum pyrolysis: Techniques and reactions. Angew. Chem. Int. Ed. Engl. 2017, 56, 14808-14835. [CrossRef] [PubMed]

2. Aitken, R.A.; Boubalouta, Y. Recent advances in the synthesis of heterocyclic compounds using flash vacuum pyrolysis. Adv. Heterocycl. Chem. 2015, 115, 93-150. [CrossRef]

3. Tietze, L.F. Domino reactions in organic synthesis. Chem. Rev. 1996, 96, 115-136. [CrossRef] [PubMed]

4. Tietze, L.; Brasche, G.; Gericke, K.M. Domino Reactions in Organic Synthesis; Wiley-VCH: Weinheim, Germany, 2006; ISBN 978-3-527-29060-4.

5. Tietze, L.F. (Ed.) Domino Reactions: Concepts for Efficient Organic Synthesis; Wiley-VCH: Weinheim, Germany, 2014; ISBN 978-3-527-33432-2.

6. Aitken, R.A.; Bradbury, C.K.; Burns, G.; Morrison, J.J. Tandem radical cyclisation in the flash vacuum pyrolysis of 2-methoxyphenyl and 2-methylthiophenyl substituted phosphorus ylides. Synlett 1995, 53-54. [CrossRef]

7. Aitken, R.A.; Burns, G.; Morrison, J.J. Flash vacuum pyrolysis of stabilised phosphorus ylides. Part 14. Tandem cyclisation of intermediate aryloxy and arylthio radicals leading to tri- and tetra-cyclic aromatic heterocycles. J. Chem. Soc. Perkin Trans. 1 1998, 3937-3941. [CrossRef]

8. Aitken, R.A.; Garnett, A.N. An eight-stage gas-phase cascade reaction leading to 7-(2-benzothienyl)benzofuran and 2,7'-bi(benzofuran). Synlett 2001, 228-229. [CrossRef]

9. Aitken, R.A.; Garnett, A.N. Cascade synthesis of new tetracyclic heteroaromatic thieno[2,3-b]pyridine-containing ring systems. New J. Chem. 2009, 33, 2402-2404. [CrossRef]

10. Aitken, R.A.; Chang, D. New gas-phase domino processes leading to benzopyranones and benzofurans. Heterocycles 2016, 93, 164-1284. [CrossRef]

11. Aitken, R.A.; Garnett, A.N. Versatile pyrolytic synthesis of fused polycyclic heteroaromatic compounds. Synthesis 2017, 49, 4955-4977. [CrossRef]

12. Aitken, R.A.; Murray, L. New gas-phase cascade reactions of stabilised phosphorus ylides leading to ring-fused indoles and to quinolines. J. Org. Chem. 2008, 73, 9781-9783. [CrossRef] [PubMed]

13. Aitken, R.A.; Murray, L. Gas-phase domino cyclisation of phosphonium ylides leading to the total synthesis of Eustifoline D. Tetrahedron Lett. 2017, 58, 4328-4332. [CrossRef]

14. Aitken, R.A.; Boubalouta, Y.; Chang, D.; Cleghorn, L.P.; Gray, I.P.; Karodia, N.; Reid, E.J.; Slawin, A.M.Z. The value of 2JP-CO as a diagnostic parameter for the structure and thermal reactivity of carbonyl-stabilised phosphonium ylides. Tetrahedron 2017, 73, 6275-6285. [CrossRef]

15. Aitken, R.A.; Karodia, N.; Lightfoot, P. The solid-state conformation of oxo stabilised ylides: X-ray structures of four new polyoxo phosphorus ylides. J. Chem. Soc. Perkin Trans. 2 2000, 333-340. [CrossRef]

16. Aitken, R.A.; Boeters, C.; Morrison, J.J. Novel Thermal Cyclisation of o-Methylstyrylalkynes to give 2-Alkenylnaphthalenes. Tetrahedron Lett. 1995, 36, 1303-1306. [CrossRef] 
17. Aitken, R.A.; Boeters, C.; Morrison, J.J. Flash vacuum pyrolysis of stabilised phosphorus ylides. Part 10. Generation of 2-methylstyrylalkynes and their thermal cyclization to 2-alkenylnaphthalenes. J. Chem. Soc. Perkin Trans. 1 1997, 2625-2631. [CrossRef]

18. Katritzky, A.R.; Vincek, A.; Suzuki, K. Microwave-assisted synthesis of peptidyl phosphorus ylides. Arkivoc 2005, v, 116-126. [CrossRef]

19. Aitken, R.A.; Horsburgh, C.E.R. Flash Vacuum Pyrolysis of O-phenylene Sulfite: Formation and Purification of Cyclopentadienone Dimer. In Comprehensive Organic Chemistry Experiments for the Laboratory Classroom; Afonso, C.A.M., Candeias, N.R., Simao, D.P., Trinidade, A.F., Coelho, J.A.S., Tan, B., Franzén, R., Eds.; Royal Society of Chemistry: Cambridge, UK, 2017; pp. 690-693. ISBN 978-1-84973-963-4.

20. Shizuri, Y.; Ojika, M.; Yamada, K. Structure of an antitumor antibiotic, reductiomycin. Tetrahedron Lett. 1981, 22, 4291-4294. [CrossRef]

21. Pardin, C.; Pelletier, J.N.; Lubell, W.D.; Keillor, J.W. Cinnamoyl inhibitors of tissue transglutaminase. J. Org. Chem. 2008, 73, 5766-5775. [CrossRef] [PubMed]

22. Patra, P.K.; Suresh, J.R.; Ila, H.; Junjappa, H. A new regiospecific method for the synthesis of substituted phenanthridines and benzo[j]phenanthridines via aromatic annelation of 1- $N$-benzenesulfonyl-3[bis(methylthio)methylene]-1,2,3,4-tetrahydroquinoline-4-one. Tetrahedron 1998, 54, 10167-10178. [CrossRef]

Sample Availability: Not Available. 